\title{
THE EFFECT OF ENVIRONMENTAL FRIENDLINESS FANATICISM OF STUDENTS TOWARDS PURCHASE INTENTION AND PURCHASE DECISION OF ORGANIC FOOD
}

\author{
Khairiyah Kamilah"), Jono Mintarto Munandar**), Muhammad Syamsun ${ }^{* *}$, and \\ Thirarut Worapishet ${ }^{* * *}$ \\ *) School of Business, IPB University \\ SB IPB Building, Jl. Raya Pajajaran, Bogor 16151, Indonesia \\ **) Department of Management, Faculty of Economics and Management, IPB University \\ Jl. Kamper Wing 4 Level 5, IPB Campus, Dramaga16680 Bogor, Indonesia \\ $\left.{ }^{* * *}\right)$ Faculty of Business Administration, Kasetsart University \\ Chandrasatitya Alley, Lat Yao, Chatuchak, Bangkok 10900, Thailand
}

\begin{abstract}
Organic food (OF) market is claimed as the fastest growing market in 20th century. Therefore, there are much research about finding factors that affect purchase intention towards OF, one of them is the Food Choice Questionnaire (FCQ), by which it is easy to assess nine distinct food choice motives and one important domain which is represented in FCQ is food choice based on ethical reasons. However, environmental protection or ecological motives is the most important motive to consume organic food. This study aims to see how fanaticism towards eco-friendly would affect the purchase intention and decision of organic food from the student's perspective. This study uses 250 respondents from agricultural universities in Indonesia and Thailand, picked by purposive sampling method. This study found that fanaticism towards environmental friendliness affects purchase intention of organic food and purchase intention, simultaneously affects the purchase decision significantly in both countries. The moderating effect of price only affects the effect purchase intention on purchase decision of organic food in Indonesia. This happens because Thailand and Indonesia have different fanatic score and level of household monthly income. This study is helped by SmartPLS 3.0 to run the SEM-PLS and VALS Survey to analyze characteristics of respondents.
\end{abstract}

Keywords: environment-friendly fanaticism, organic food, purchase intention, purchase decision, VALS Survey

Abstrak: Pasar makanan organik (OF) diklaim sebagai pasar dengan pertumbuhan tercepat di abad ke-20. Oleh karena itu, banyak penelitian tentang faktor-faktor yang mempengaruhi minat beli terhadap OF, salah satunya adalah Food Choice Questionnaire (FCQ), dimana FCQ ini membuat mudah untuk peneliti menilai sembilan motif pemilihan makanan yang berbeda. Satu domain penting yang terwakili dalam FCQ adalah pilihan makanan berdasarkan alasan etis. Perlindungan lingkungan atau motif ekologis merupakan motif terpenting dalam mengkonsumsi makanan organik berdasarkan penilaian ethical reason dalam FCQ. Penelitian ini menggunakan masing-masing 250 responden dari perguruan tinggi berbasis pertanian di Indonesia dan Thailand. Studi ini menemukan bahwa fanatisme terhadap keramahan lingkungan mempengaruhi minat beli pangan organik, dan minat beli secara simultan berpengaruh signifikan terhadap keputusan pembelian di kedua negara. Pengaruh moderasi harga hanya berpengaruh pada pengaruh niat beli terhadap keputusan pembelian pangan organik di Indonesia. Hal ini terjadi karena Thailand dan Indonesia memiliki skor fanatik dan tingkat pendapatan bulanan rumah tangga yang berbeda. Penelitian ini dibantu oleh SmartPLS 3.0 untuk menjalankan SEM-PLS dan VALS Survey untuk menganalisis karakteristik responden.

Kata kunci: fanatisme terhadap eco-friendly, keputusan pembelian, makanan organik, minat beli, survey VALS

\footnotetext{
${ }^{1}$ Corresponding author:

Email: khairiyah-kamilah@apps.ipb.ac.id
} 


\section{INTRODUCTION}

Organic food (OF) market is claimed as the fastest growing market in 20th century (Hamm and Gronefeld, 2004). Global sales of organic products have reached US \$46.1billion in 2007 (Willer and Kilcher, 2009) with the growth of the global market revenue of 43 percent between 2002 and 2005 Sahota (2007). This happens because nowadays, consumer tends to look for healthy food (Siregar et al. 2019) and GMO (genetical modification organism) free (Chryssohoidis and Krystallis, 2005; Davis et al. 1995). Therefore, there is much research about finding the factors that affect purchase intention towards OF to be implemented by OF companies. Steptoe, Pollard and Wardle (1995) developed the Food Choice Questionnaire (FCQ), by which, it is easy to assess nine distinct food choice motives and one important domain which is represented in FCQ is food choice based on ethical reasons (Lindeman and Vaananen, 2000). The Ethical Concern subscale of FCQ includes three items, one of them addresses political approval of the country of the food's origin, one labeling the country of the food's origin, and one environmental protection. However, environmental protection or ecological motives is the most important motive to consume organic food (Lindeman and Vaananen, 2000) and it also has the strongest impact on attitude of organic food for consumers. Based on past researches, this research aims to know the impact of environment-friendly fanaticism towards purchase intention. Fanaticism can lead to brands, products, services, actors/actresses, athletes, consumption of certain products and experiences (Deveci and Ercis, 2017).

The effect of purchase intention on purchase decision of OF is also measured in this study. Hansen et al (2004) and Lee and Lee (2013) stated that the chance for a purchase to be actualized is higher if the purchase intention is strong. Consumers make actual purchases if driven by positive buying interest in consumers (Wu et al. 2011). Regarding Liang (2015), purchase intention and purchase decision towards OF can be changed when different scenarios of price are included as a variable. Therefore, this research includes price as moderating variable. This research used SEM-PLS as analyzing tools with 250 respondents in each country based on amount of indicators asked in the questionnaire (Ferdinand, 2014).
Indonesia and Thailand have been picked as objects of this study are because of some reasons; both countries are included in the top 10 largest organic farming land in the Asia Pacific, which is the biggest and largest market of OF in the world. Thailand and Indonesia, at the same time, are included as the top 5 countries in the world that account for plastic bags trash to the ocean (BBC News- World, 2018). As the issue of this environmental harassment is increasing, both countries join campaigns to save the world by saving nature. Indonesia joins campaign called "no plastic straw movement" and it has been all over the internet as reported by Google Trends 2018. Besides, Indonesia also has committed to reducing its marine litter by 70 percent by 2025 (United Nations- Environment Department, 2018).

Thailand also joins campaigns regarding reducing plastic bags to prove its concern for the environment and animal welfare. As reported by United Nation Environment in 2018, Thailand has done FL recycling since 2010, and with UN ESCAP launched a policy in Bangkok to not allow the use of plastic straw and single-use plastic. Thailand also signed a memorandum of understanding with private sector companies to reduce 50 percent of its waste in the ocean.

The decreasing of OF market growth in the world needs to be analyzed since the growth of world population is increasing rapidly. The increasing world population should affect the demand for food. The demand for OF also should be increasing as mentioned in some studies before. This decreasing of OF market growth becomes a problem of this study. This study aims to know how to make the increasing of OF market growth by analyzing its strength. One of the strength OF has is its ethics towards environment that doesn't harm environment and animals. This study uses the fanaticism (Marimaa, 2011) of environmental friendliness of consumers as independent variable, to analyze whether it affects purchase intention of OF or not (H1. Fanaticism affects purchase intention of $\mathrm{OF}$ ) and how this simultaneously affects purchase decision of OF (H2. Purchase intention affects purchase decision of OF). It also uses price as moderating variable to see how to purchase intention affects purchase decision of OF (H3. Price as moderating variable affects purchase intention towards purchase decision of OF). 


\section{METHODS}

This research takes place in agriculture university in Thailand and Indonesia from January 2019 to March 2019. The type of data used in this study are primary data and secondary data. Primary data is obtained through a closed questionnaire technique with six-Likert-scale to answer the questions on the closed questionnaire and an opened questionnaire given to 250 respondents from Thailand and 250 respondents from Indonesia who are bachelor degree students of agricultural universities. Secondary data sources are obtained from supporting data through literature studies, marketing textbooks and electronic books, research methods, and national and international journals.

Sampling Method

According to Firdaus and Farid (2008), the requirements for adequate numbers of respondents to be used in SEM analysis amounted to between 100 and 200 respondents. While, according to Ferdinand (2014), minimum sample needed in SEM is five times the indicators analyzed in the research. This research uses 43 indicators so that the minimum amount of sample needed is 43 times 5 equal 215 each country. All the samples are picked by purposive sampling method which has category (1) the samples are bachelor/magister degree students (2) actively use the eco-friendly product in daily activities (3) have bought organic food product at least once.

Data processing is done using Microsoft Excel 2010, SPSS and SmartPLS 3.0 to run the structural equation modelling (SEM). SEM combines two separate statistical methods; factor analysis and simultaneous equation models (Hair, 2014; Ghozali, 2016). The variables shown in SEM are latent variables and manifest variables. The latent variables consist of exogenous and endogenous variables. Exogenous constructs independent variables while endogenous constructs dependent variables. Whereas, the manifest variable or indicator variable is manifested in the form of a six-Likert-scale question.

This study uses quantitative data analysis, which means the data used in this study can be calculated with a number of certain units or expressed by numbers. This analysis includes data processing, organizing data and finding results. The components used in the general SEM model in this study consist of the exogenous variables in Table 1.
SEM analysis consists of two equation models namely structural equation models and measurement equation models. The research model of this study is an equation of the structural model, which can be seen in Figure 1.

Value, Attitude, and Lifestyle (VALS) Survey is used in this study to know better about respondents' characteristics and figure out about marketing strategies needed. VALS segments US adults into eight distinct types or mindsets using a specific set of psychological traits and key demographics that drive consumer behavior. The US Framework, a graphic representation of VALS, illustrates the eight types and two critical concepts for understanding consumers: primary motivation and resources. The combination of motivations and resources determines how a person will express himself or herself in the marketplace as a consumer.

The decreasing of OF market growth in the world also happens in the Asia Pacific region, the largest market of OF and largest area of organic farming land in the world. This gives threats to the market of OF. Industrialized organic agriculture can be the issue of this decreasing phenomenon. Organic food that is claimed environmental friendly (EF) because it doesn't contain pesticides and doesn't harm animals and environment, can't help the growth even though EF campaign is now widely spreaded by medias worldwide. In contrast, Indonesia as the 4 th largest organic farming land in Asia- Pacific region experiences increasing of $\mathrm{OF}$ market growth for the last 5 years, while Thailand, as the 8th organic farming land in Asia Pacific region experiences decreasing. Even though Indonesia and Thailand also support several EF campaigns, the trends of market growth in two countries are different. This research aims to analyze the effect of EF fanaticism towards purchase intention and how to purchase intention affects purchase decision with price as moderating variable. Framework of this study can be seen in Figure 2.

\section{RESULTS}

The result of this study can be seen in Figure 3 and Figure 4 (Thailand). Some characteristics of fanaticism towards environment friendliness (EF) affect purchase intention of organic food significantly. Thailand and Indonesia have different results about which variables affect purchase intention significantly. The difference is shown in Table 2. 
Table 1. Dimension of exogenous variables and indicators

\begin{tabular}{lll}
\hline Variable & Sub Variable & Definition \\
\hline Fanaticism & $\begin{array}{l}\text { Enthusiasm } \\
\text { (X1) }\end{array}$ & $\begin{array}{l}\text { a high level of intensity, interests, } \\
\text { activities, desires and joys. } \\
\text { Awareness to not being negative } \\
\text { because of OF. } \\
\text { the desire to pursue something or } \\
\text { to support someone or an object, } \\
\text { or to achieve a certain goal }\end{array}$ \\
& Zeal (X2) \\
& $\begin{array}{l}\text { inappropriate attitude, things that } \\
\text { are exaggerated, and frenzied }\end{array}$
\end{tabular}

Cult (X4)

Devotion (X5)

Inertia behaviour (X6)

Self satisfaction (X7)

Price (X8)

Purchase Intention (Y1)

Purhase Decision (Y2) seeing only from one point of view, dogmatic (arrogant), incorrigible, closed mind, uncompromising and rigid in certain provisions

loyalty and devotion consider not simply the frequency of participation, such as usage or purchase patterns, but involves emotional attachments such as feelings of passion and love, intimacy and dedication

Addiction and obsessivecompulsive behaviors that are intrusive to individuals and ultimately cause harm to them or others

Someone consumes something because of the pleasure he gets from something. A fanatic person can consume something without thinking as long as it gives him satisfaction

Value that is paid by consumer to be exchanged with value from a product

Purchase Intention is something that represents consumers who have the possibility, will, plan or are willing to buy a product or service in the future

Purchase decision is an activity whether or not a market target buying the product. This occurs when there are several alternatives.

Indicator

time spend on exploring EF campaign

Redden and (x11), money spend on EF stuff (x12),

Steiner (2000) product EF bought (x13), awareness of being "too much" (x14)

supporting EF campaign (x21), achieve goals with EF (x22), purchasing EF

Redden and stuff (x23)

get angry at someone who insulted EF campaign ( $\mathrm{x} 31$ ), scold at someone who insulted EF campaign (x32), scold someone who insulted environment (x33)

$\mathrm{EF}$ is the only way to save the world (x41), everyone who doesn't support $\mathrm{EF}$ campaign is uneducated person Steiner (2000)

Redden and Steiner (2000) (x42), always support EF forever (x43), everyone who supports EF campaign is a good person (x44)

Frequency OF : usage EF products (x51), purchase EF products (x52), get angry at someone who insulted environment (x53), advise someone who insulted environment (x54), support EF campaign even no one does (x55)

feel compelled to buy EF stuff (x61), feel need to buy EF stuff even it's useless (x62), borrow money to buy EF stuff (x63), feel exhausted when someone insulted environment (x64), not feeling safe when using or doing something non $\mathrm{EF}$ (x65)

Get bored doing EF campaign (x71), get bored with EF stuff (x72), spend last source to support EF campaign and buy EF stuff (x73), enjoy supporting Efin daily life (x74)

Still buy OF even it's more expensive than regular food (x81), not buying OF because it's more expensive than regular food (x82)

Very likely to choose: organic vegetables (y11), organic rice (y12),

Chung et al. (2008), Redden and Steiner (2000)

Chung et al. (2008)

Chung et al. (2008)

Chung et al. (2008) organic fruit (y13), organic meat (y14), organic processed food (y15).

Consuming OF nowadays (z11), buy OF very soon (z12), willing to spend money for OF (z13), there are many alternatives, but $\mathrm{OF}$ is the one that bought (z14), will buy OF again in future (z15), OF is the first choice when it comes to food (z16), OF is the most safe food (z17), recommend OF to others (z18).
Pride and

Ferrel (2014), Kotler and Keller (2008) Hidayati et al. (2013), Putra et al. (2016) 


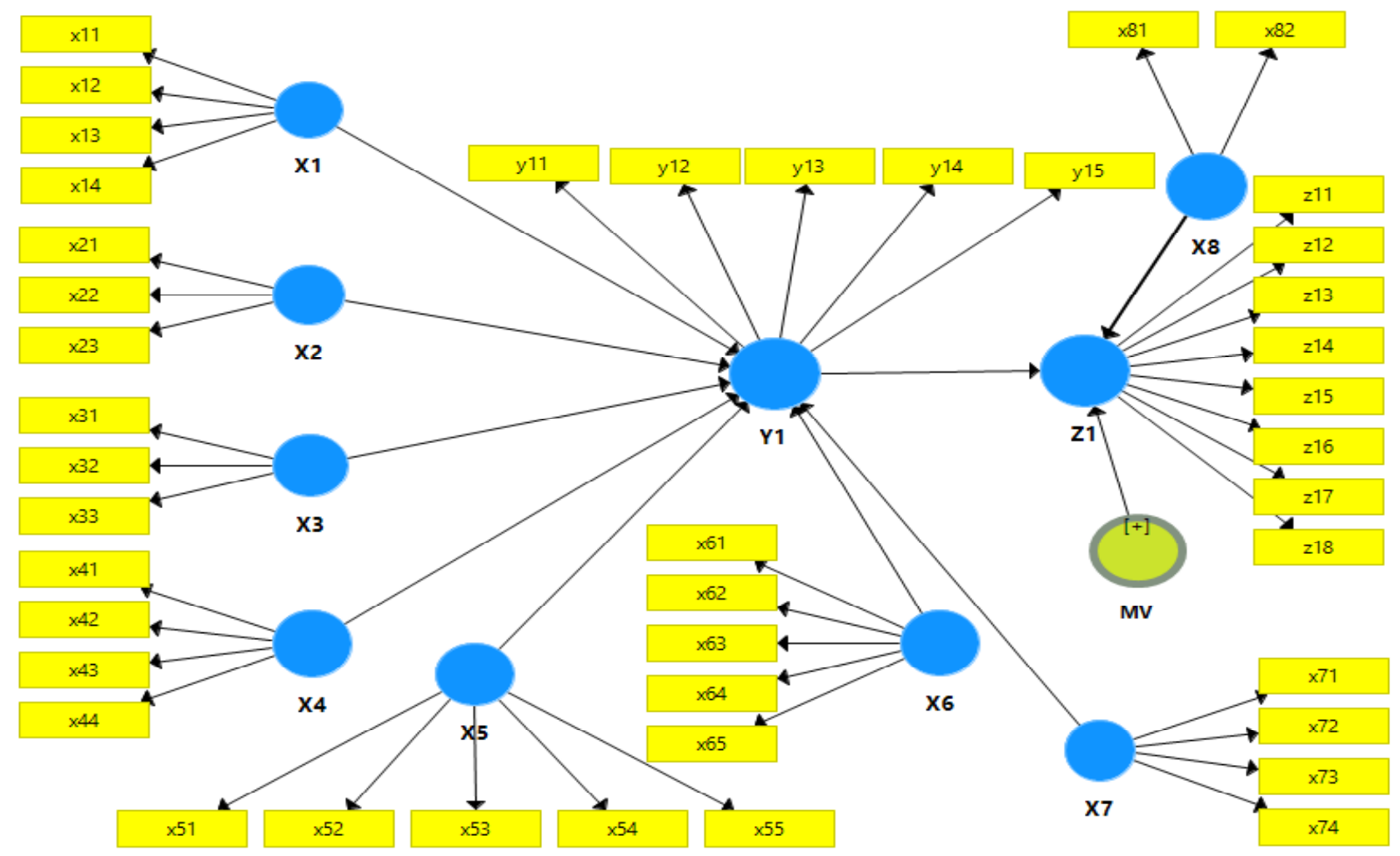

Figure 1. Research model

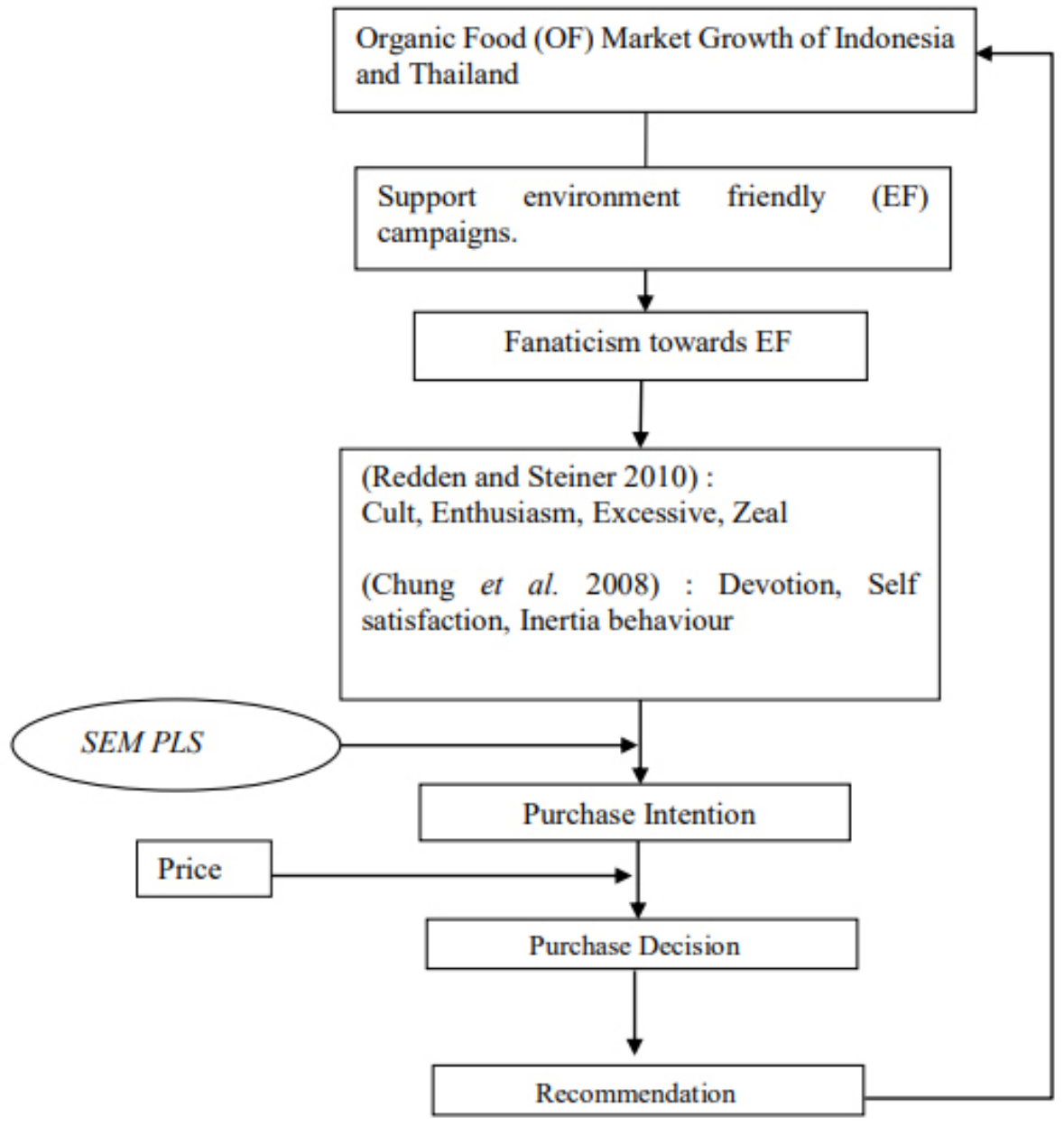

Figure 2. Research framework 


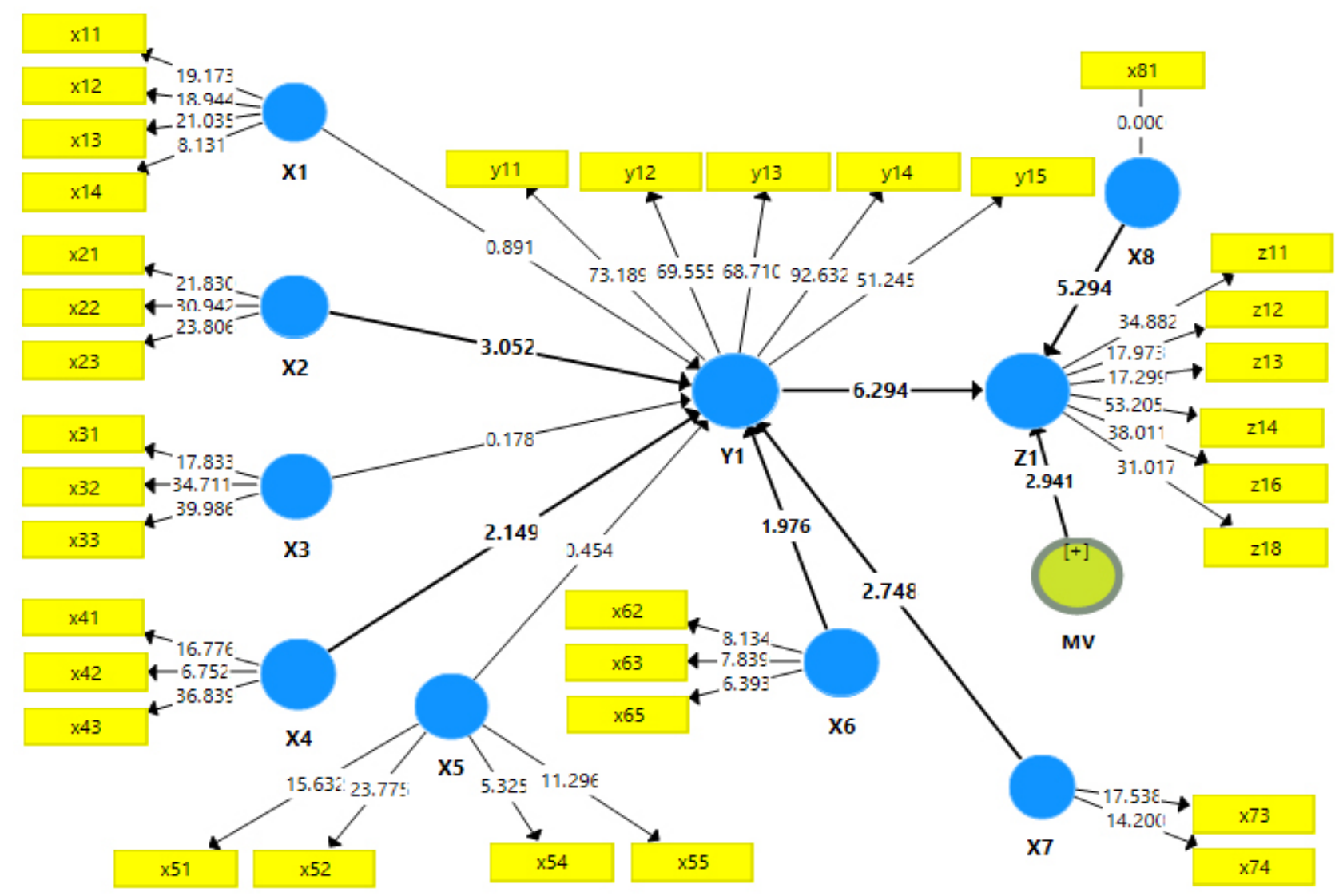

Figure 3. Model and significant variables (Indonesia)

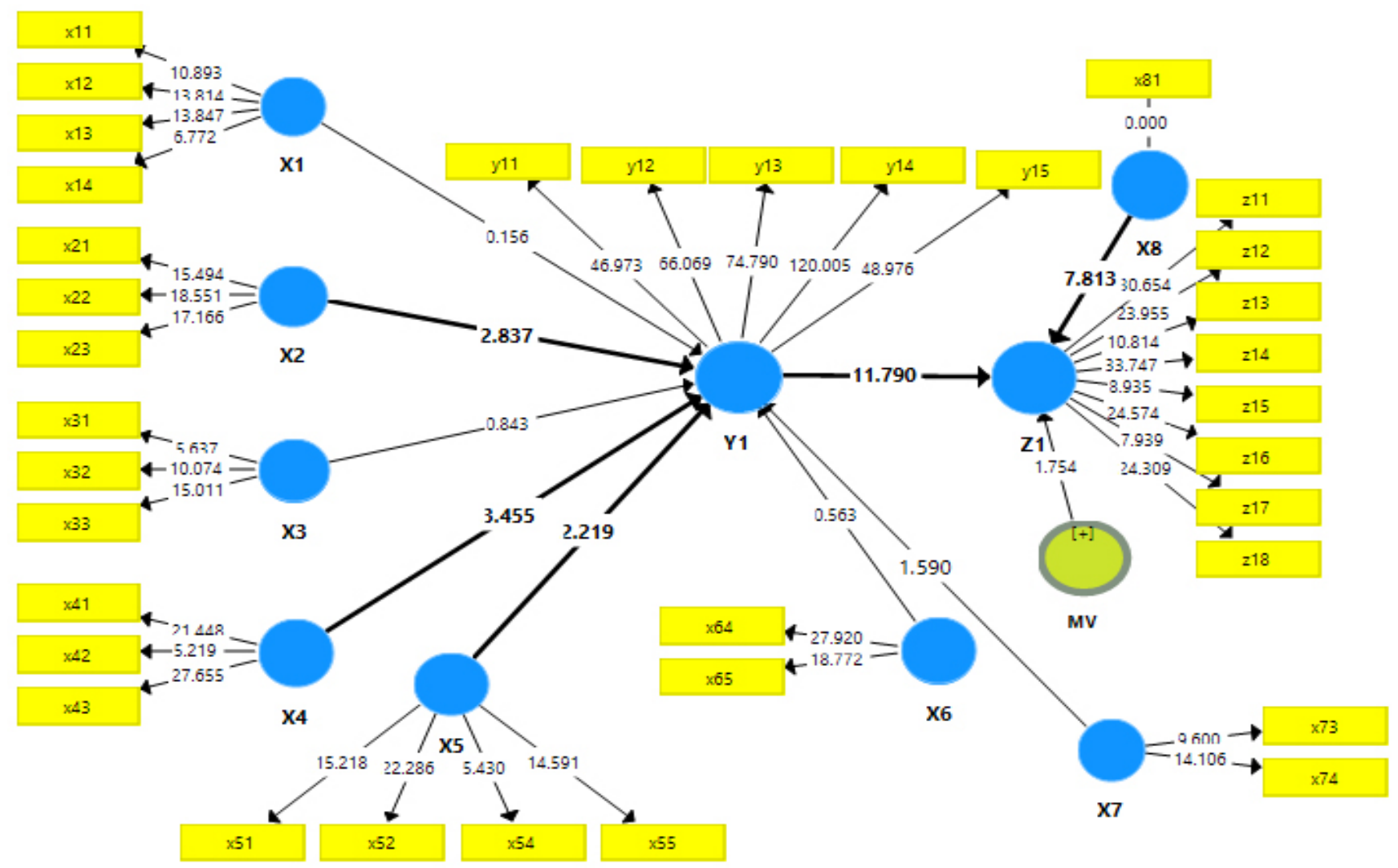

Figure 4. Model and significant variables (Thailand) 


\begin{tabular}{lcccc}
\hline & \multicolumn{2}{c}{ Indonesia } & \multicolumn{2}{c}{ Thailand } \\
\cline { 2 - 5 } & T-Statistic & Hypothesis & T-Statistic & Hypothesis \\
\hline Cult (X4) $\rightarrow$ Purchase Intention (Z1) & 2.149 & Significant & 3.455 & Significant \\
Devotion (X5) $\rightarrow$ Purchase Intention (Z1) & 0.454 & Not Significant & 2.219 & Not Significant \\
Enthusiasm (X1) $\rightarrow$ Purchase Intention (Z1) & 0.891 & Not Significant & 0.156 & Not Significant \\
Excessive (X3) $\rightarrow$ Purchase Intention (Z1) & 0.178 & Not Significant & 0.843 & Not Significant \\
Inertia Behaviour (X6) $\rightarrow$ Purchase Intention (Y1) & 1.976 & Significant & 0.563 & Significant \\
Moderating Effect (MV) $\rightarrow$ Purchase Decision & 2.941 & Significant & 1.754 & Significant \\
Price (X8) $\rightarrow$ Purchase Decision (Z1) & 5.294 & Significant & 7.813 & Significant \\
Purchase Intention (Y1) $\rightarrow$ Purchase Decision (Y1) & 6.294 & Significant & 11.790 & Significant \\
Self Satisfaction (X7) $\rightarrow$ Purchase Intention (Y1) & 2.748 & Significant & 1.590 & Significant \\
Zeal (X2) $\rightarrow$ Purchase Intention (Y1) & 3.052 & Significant & 2.837 & Significant \\
\hline
\end{tabular}

Indonesia and Thailand show different variables of fanaticism significantly affect purchase intention of organic food (OF). There are 4 variables of fanaticism that affect purchase intention of $\mathrm{OF}$ in Indonesia; zeal (x2), cult (x4), inertia behaviour (x6) and selfsatisfaction (x7). Meanwhile, in Thailand, there are only 3 variables of fanaticism that affect purchase intention of OF significantly; zeal (x2), cult (x4), and devotion (x5). Zeal and cult are variables that Indonesia and Thailand have in common that affect purchase intention of OF significantly. This can happen because both countries participated in some EF campaigns and have a spirit to implement them. In Indonesia, this phenomena of zeal (the desire to pursue and support someone or something; spirit) can happen because many of EF campaigns are spreaded through social media; such as Instagram, Twitter, etc. Based on APJJI (2018), social media users in Indonesia mostly come from the age range $19-34$ (49.95\%) which is in the same range with all the respondents' age (can be seen in Table 3). Respondents with high intensity of using social media must have been exposed to many campaigns and concerns regarding the environmental crisis and become fanatic towards EF. In Indonesia, the search history of stainless steel straw is also increasing by the end of 2018 (Google trends) means Indonesian citizens concern about environmental issues.

While, in Thailand, the citizen seems to pursue their goals becoming the most visited country in Southeast Asia. As reported by Agoda.com, one of the biggest sites for travelers, Thailand is the top-visited country in Asia by 2018. While pointing to research from Henkel et al. (2006), cleanliness is the most significant item when considering tourism destination based on international and Thai tourist perceptions. This can be one of the reasons Thailand citizen is keeping the country's cleanliness (Henkel et al. 2006) and being as environmentally friendly as possible.

Zeal phenomena are also known because some cities in Indonesia and Thailand have supported campaigns with no single used plastic through their major regulations. One of them is major city in Indonesia, Bogor has released the regulation of forbidding single used plastic bags through Major Regulation No. 612018 and Bangkok, capital city of Thailand, has forbidden the use of single used plastic bags and straws as mentioned in catalogue from United Nation-Environment Department by 2018 . These regulations show how both countries are in the spirit to support EF.

Self-satisfaction (x7) and inertia behaviour (x6) become 2 variables that significantly affect purchase intention of organic food in Indonesia. This can be caused by the fact that Indonesia is the most consumptive country in Southeast Asia (World Bank, 2017) that can lead to behaviour of self-satisfaction and inertia behaviour. The respondents who are fanatic towards EF become consumptive in buying and supporting EF stuff and campaigns. Purchase intention of OF is significantly affected by these two variables is because consumers' attitudes toward buying organic food are positive to the extent that they believe organic food is better for the environment or eco-friendly (Aertsens et al. 2009; Hughner et al. 2007; Thøgersen 2010; Torjusen et al. 2004).

Loyalty and emotional attachments can define devotion (Chung et al. 2008) that leads to fanaticism. These emotions towards EF campaigns or activities in Thailand can be influenced by their saintly emotional 
attachments towards the King (Kim, 2015). As we know, Thailand government has signed some of memorandum of understanding about keeping the environment safe for plants and animals (Environment Department-UN, 2017), and this is one of its citizen's ways to support the government and the King.

All these characteristics of fanaticism towards EF can affect purchase intention of OF significantly because OF is known to be the choice of consumers because it is eco-friendly products (Olsen, 2006) and get positive attitude from consumers because of its ethic towards environment (Hsu and Chen, 2014). The answers to opened questions on questionnaire in this study also show that the image of organic food is eco-friendly and brand image is an important factor in purchase decision through purchase intention (Febriyanti, 2016).

This phenomena can be used by marketers of OF companies to increase the growth of OF sales. Marketers need to do repositioning OF not only as healthy food (Hsu and Chang, 2016), but also has value of environmental friendly to aim the consumers who are looking for healthy food and who are fanatic towards EF. Respondents of this study in both countries are categorized as Experiencers and Strivers based on VALS Survey. From this survey, consumers can be grouped as one or two types of costumer and make it easy for marketers to make marketing strategies based on their type. As Experiencers and Strivers group, the respondents in this study believe that friends are extremely important and they are very imitative.
Due to those types, the promotion using peer group, celebrity, or other reference groups as endorser will be the most effective way to promote OF in Indonesia and Thailand.

Both Indonesia and Thailand show that purchase intention affects purchase decision of organic food significantly. This result is proven from Kusumawardhani's past study (2018) about how to purchase intention significantly affects purchase decision. Kotler and Keller (2008) also stated the same theory. Table 2 shows that purchase intention affects purchase decisions positively (T-Statistic more than 1.96). This means, the stronger intention of purchasing something, the higher a chance of actual purchase occurs. This also gives the same result with Hansen et al (2004) and Lee (2013) past research.

Purchase decisions can occur after the consumers have intention to buy product after problem recognition, seeking information, and evaluation of alternatives (Kotler and Amstrong, 2008). In making purchases, consumers are likely to evaluate the revenue, prices and product value or benefit (Kotler and Amstrong, 2008). Organic food has value that all EF fanatics want: safe for environment (Sivathanu, 2015; Mia, 2009). OF gives no harm to environment and free chemical pesticide because in the process of planting, OF relies on animal and plant manures (Department for Environment Food and Rural Affairs the United Kingdom) that can make the intention of buying OF is stronger and the chance of actual purchasing is higher (Nugroho et al. 2015).

Table 3. Characteristic of respondents

\begin{tabular}{lll}
\hline Characteristic & Thailand & Indonesia \\
\hline Gender & $32 \%$ Male & $34 \%$ Male \\
& $68 \%$ Female & $66 \%$ Female \\
Age & $68 \% 15-22$ years old & $99 \% 15-22$ years old \\
& $32 \% 23-30$ years old & $1 \% 23-30$ years old \\
Total household monthly income & $1 \%$ THB $10.000-30.000$ & $35 \%$ Rp2.500.001- Rp5.000.000 \\
& $47 \%$ THB $30.001-50.000$ & $40 \%$ Rp5.000.001- Rp 10.000 .000 \\
& $19 \%$ THB $50.001-70.000$ & $17 \%$ Rp $10.000 .001-$ Rp 20.000 .000 \\
Marital Status & $33 \%$ THB 70.000 and more & $8 \%$ Rp20.000.001 and more \\
Latest formal education & $100 \%$ not married & $100 \%$ not married \\
VALS Survey (Psychological and demographic & $98 \%$ of Experiencers or Strivers & $98 \%$ of Experiencers or Strivers \\
questions) & & \\
\hline *assumption THB 1 = Rp450 & &
\end{tabular}


Price (X8) as moderating variable gives different effect in the effect of purchase intention on purchase decisions in Indonesia and Thailand. Price as moderating variable affects the effect of purchase intention on purchase decision of organic food significantly in Indonesia (Nugroho et al. 2015). It can be seen in Table 2 that moderating variable has T-statistic value of 2.941 which is greater than 1.96 and categorized as significant effect. This means that different scenario of price of OF affects the effect of purchase intention on purchase decision. This result is the same with Liang (2015) past research that stated effect of purchase intention towards purchase decision can be changed when different price scenario is included as variable. The lack of trust from Indonesia's citizens also can be the reason. The moderating variable of price gives positive effect means that the higher the price is, the higher purchase activity will occur. This also similar to research by Marian and Thøgersen (2013) that stated when consumers lack trust, they actively seek external clues to increase the willingness to buy, and one of those external clues is price (Liang, 2015).

While, in Thailand, moderating variable doesn't affect the effect of purchase intention on purchase decision. Table 2 shows that T-statistic of moderating variable is 1.754 which is lower than 1.96 and it means moderating variable has no significant effect. This means that no matter how much the price is, as long as the consumer has intention to buy, then the purchasing will occur.

The different effects of moderating variables in both countries are caused by fanatic score and the monthly income of respondents. Indonesia has average fanatic score of 3.604 while Thailand has average fanatic score of 3.857. These scores indicate Thailand's respondents are more fanatic towards EF than Indonesia's. As mentioned in Chung et al. (2008), someone who is fanatic towards something/ someone is willing to spend the last resource such as time and money to support someone or to buy something he/ she is fanatic about, so price is not significant variable if she/ he already has intention to buy.

Besides fanatic score in each country and the monthly income in each country also affects the effect of moderating variable in this study. From Table 3, we can see that Thailand's respondents' monthly income is way higher than Indonesia's. This is related to the finding of Iqbal (2015) research, that level of income affects purchase decision of OF. It is because the premium pricing of $\mathrm{OF}$ is accessible to the middle classes onwards (Iqbal, 2015).

\section{Managerial Implications}

Fanaticism is a psychological activity of an individual where she/ he likes individual figure, group, trends, artwork, certain idea, or value (Thorne and Bruner 2006). In this study, EF is the value. Results from Indonesia and Thailand show that fanaticism towards EF affects purchase intention of OF significantly positive. This means, more fanatic the person in both countries, the intention to buy OF is stronger. This phenomenon can be used by marketers of OF company to increase the growth of OF sale. Marketers need to do repositioning OF not only as healthy food but also has value of environmentally friendly to aim at the consumers who are looking for healthy food and who are fanatic towards EF. Respondents of this study in both countries are categorized as Experiencers and Strivers based on VALS Survey. From this survey, consumers can be grouped as one or two types of costumer and make it easy for marketers to make marketing strategies based on their type. Both groups, Experiencers and Strivers are typically had motivations to achieve something and to express themselves. They need value to get in their lives, so it is a wise strategy to install the value of EF in $\mathrm{OF}$ and promote this value to customer by positioning the product as EF product.

More specifically, factors of fanaticism that significantly affect purchase intention are zeal, cult, devotion, inertia behaviour, and self-satisfaction. From these results, marketers of OF in Thailand and Indonesia can apply some strategies since zeal and cult of EF are factors that significantly affect purchase intention of $\mathrm{OF}$ in both countries. Since "zeal" of EF is a desire to support EF and desire to pursue something through EF, marketers or companies can make strategy from packaging and communication aspect; the packaging should not harm environment; no styrofoam, no non-degradable plastics to show customers that our product is supporting EF and match with the value they believe. This also should be communicated through the products' label so customers will be aware of the OF products' value in supporting EF. While, "cult" makes someone sees only from one point of view, dogmatic, close-minded, and rigid. They believe that the ones who support EF are a good, educated person and the ones who do not are vice versa. Thus, OF companies can distribute the product with a selective or exclusive distribution strategy. 
Devotion to $\mathrm{EF}$ is the factor of fanaticism that significantly affects purchase intention of $\mathrm{OF}$ in Thailand. This is connected to the fact that Thailand is a country with high loyalty and emotional attachment to its king (Kim, 2015). Since devotion means feelings of love, beyond loyalty, and involves high emotional attachment, the people of Thailand have it all towards the king and the country. So, when the country has signed a memorandum, done a campaign regarding EF, the Thai also support as intense as they can to the programs. With this fact, company can apply programs that are in the same value as the government regarding EF or be a part of the program. For example, when single used plastic straw is forbidden in Bangkok, companies could join this campaign to pull customers. Inertia behaviour and self-satisfaction are pointing to consumptive behaviour. In Indonesia, these two factors affect purchase intention of OF significantly proved that students in Indonesia are relatively consumptive. This result is also supported by data from World Bank (2007) that Indonesia is the most consumptive country in ASEAN. Consumptive behaviour is good opportunity for companies because they can sell the products easily. OF companies can make use of these factors to sell OF products and relate the products to $\mathrm{EF}$ campaign to gain the customers who are consumptive. For example, the companies can make programs like serial gift, mysterious box, completing stuff that support EF campaign/ activities every time they buy OF products.

The values that have been instilled in OF products shouldn't be saved by companies. These need to be promoted to let consumers and prospective consumers know about the new value of OF. Because, as Zeithaml (1988) and Septifani (2014) mentioned in their research, in purchase decision process, consumer affected by several variables and one of them is the value that is offered by the products. When the consumers are sure they will get the value they search for, they will interest to buy and lead to actualizing the purchase. In this study, the value of EF needs to be promoted as a value that consumers will get if they buy the OF. This value will affect consumers' intention to buy and lead to purchase decisions (Sivathanu, 2015; Septifani et al. 2014). As Experiencers and Strivers group, the respondents in this study believe that friends are extremely important, and they are very imitative. Due to those types, the promotion using peer group, celebrity, or other reference groups as an endorser will be the most effective way to promote OF in Indonesia and Thailand.
Even the product is well promoted by marketers or companies when prospective consumers can't access the products due to pricing problem, the strategy will be useless. In Indonesia, price still affects the effect of purchase intention towards purchase decision significantly (Liang, 2015). The consumers in Indonesia is willing to buy OF because the value offered as ecofriendly and healthy product, but lack in trust issue if the price is considered low (Suharjo, 2016). There are several ways to get out of this problem. While Indonesia's citizen is lacking in trust towards the products those labeled as "organic", the consumers begin to seek for extrinsic clues. One of extrinsic clues must be the focus in the high-price organic food scenario, e.g., by delivering information through the service personnel of the organic store to improve consumer awareness of organic food and thus raise their purchase intentions (Liang, 2015).

While in Thailand, respondents are not affected by the price when they are fanatic towards EF and have intention to buy OF. The fanaticism towards $\mathrm{EF}$ in Thailand is shown when the demand for 'safe' foods increases due to scares related to high levels of pesticide residues sometimes found on vegetables and fruits (Schobesberger et al. 2007). The main reasons for purchasing OF are that consumers expect them to be environmentally friendly and healthier. The main barrier to increase the market share of organic vegetables is that consumers do not clearly differentiate between the various 'pesticide safe' labels and the organic labels (Schobesberger et al. 2007). Informing consumers about unique characteristics of organic production methods, the strict inspection and required third-party certification might be a promising strategy to develop the market for OF in Thailand.

\section{CONCLUSIONS AND RECOMMENDATIONS}

\section{Conclusions}

Most of the respondents are in the group of age 1522 years old because the bachelor degree students that are aimed as respondents for this study belong to this group. From VALS survey, 98\% of respondents from Thailand and Indonesia are both Experiencers and Strivers. Fanaticism towards EF affects purchase intention of OF significantly in both countries. There are 4 variables of fanaticism that affect purchase 
intention of OF in Indonesia; zeal (x2), cult (x4), inertia behaviour (x6) and self-satisfaction (x7). Meanwhile, in Thailand, there are 3 variables of fanaticism that affect purchase intention of OF significantly; zeal (x2), cult (x4), and devotion (x5). All these characteristics of fanaticism towards EF can affect purchase intention of OF significantly because OF is known to be the choice of consumers because it is eco-friendly products and get a positive attitude from consumers because of its ethic towards environment.

When purchase intention occurs, there is a chance that the actual purchase happens. Both Indonesia and Thailand show that purchase intention affects purchase decision of organic food significantly and positively. This means, the stronger intention of purchasing something, the higher a chance of actual purchase occurs. In making purchases, consumers are likely to evaluate the revenue, prices and product value or benefit. Organic food has value that all EF fanatics want: safe for environment.

Price as moderating variable price affects the effect of purchase intention on purchase decision of organic food significantly only in Indonesia. This means that different scenario of price of OF affects the effect of purchase intention on purchase decision. While, in Thailand, the moderating variable doesn't affect the effect of purchase intention on purchase decision. This means that no matter how much the price is, as long as the consumer has intention to buy, then the purchasing will occur. The different effects of moderating variable in both countries are caused by fanatic score and the monthly income of respondents. In this study, Thailand has higher scores for both fanatic scoring and household monthly income, that's why moderating variable doesn't give any significant effect in Thailand.

\section{Recommendations}

Based on the results of this study, some recommendations are given to organic food marketers and companies. From a "products" point of view, organic food companies need to instill the value of environmentally friendly to their products and informing consumers about unique characteristics of organic production methods, the strict inspection and required third-party certification might be a promising strategy to develop the market. Companies need to emphasize the values of organic food by putting the information on the label, or promoting the repositioning of the products.
Repositioning is needed because OF is known for environmentally friendly and healthy, but only the "healthy" value that is carried in the image of OF. By emphasizing the EF value, companies and marketers can increase the market growth and expand the market of OF; not only for those who care about health but also for those who care about the environment.

Promoting the products also needed to increase the sales of OF. Not only promoting the products, but also the values that are instilled in the products. Promoting in an exact way is needed to minimize the marketing budget. Therefore, this study uses VALS Survey to know the respondents' characteristics as consumer groups in the market. The result of VALS Survey provides marketers to decide the most effective way to communicate with consumers based on the characteristics of each group. Based on this study, the respondents are experiencers and strivers. The most effective way to promote EF value in OF products for experiencers and strivers is by using celebrity, reference group, or peer group as endorser.

\section{REFERENCES}

Chung E, Beverland MB, Farrelly FQ. 2008. Exploring consumer fanaticism: extraordinary devotion in the consumption context. Journal of Advances in Consumer Research 35(4): 333- 340.

Chryssohoidis G, Krystallis A. 2005. Organic consumers' personal value research: testing and validating the list of values (LOV) scale implementing a value-based segmentation task. Food Quality and Preference 16: 585-599. https://doi.org/10.1016/j.foodqual.2005.01.003.

Davis A, Titterington A, Cochrane C. 1995. Who buys organic food? A profile of the purchasers of organic food in Northern Ireland. British Food Journal 97(1):17-23. https://doi. org/10.1108/00070709510104303.

Deveci G, Ercis A. 2017. Determining the influence of fanatical tendencies on consumption styles based on lifestyles. AIMI Journals 4(2017): 3349. https://doi.org/10.33844/mbr.2017.60418.

Febriyanti RS, Aniek E. 2016. Pengaruh celebrity endorser dan brand image terhadap purchase decision melalui minat beli. Jurnal Ilmu dan Riset Manajemen 5(5): 1-18

Ferdinand A. 2014. Metode Penelitian Manajemen. Semarang: BP Universitas Diponegoro. 
Firdaus M, Farid MA. 2008. Aplikasi Metode Kuantitatif Terpilih Untuk Manajemen dan Bisnis. Bogor: IPB Press.

Ghozali I. 2014. Structural Equation Modelling (SEM) Metode Alternative dengan Partial Least Square. Semarang: Penerbit Universitas Dipenogoro.

Hair JE, et al. 2014. A Primer of Partial Least Square Structural Equation Modeling (PLS-SEM). California: SAGE Publication Inc.

Hamm U, Gronefeld F. 2004. The European Market for Organic Food: Revised and Updated Analysis, Organic Marketing Initiatives and Rural Development. Wales: University of Wales.

Hansen T, Møller Jensen J, Stubbe SH. 2004. Predicting online grocery buying intention: a comparison of the theory of reasoned action and the theory of planned behavior. International Journal of Information Management 24(6): 539-550. https://doi.org/10.1016/j.ijinfomgt.2004.08.004.

Henkel R, Henkel P, et al. 2006. Thailand as a tourist destination: Perceptions of international visitors and Thai residents. Asia Pacific Journal of Tourism Research 11(3):269-287. https://doi. org/10.1080/10941660600753299.

Hidayati TA, Surhayono, Fanani D. 2013. Pengaruh citra merek terhadap minat beli dan purchase decision konsumen (survei pada mahasiswa penghuni Ma'had Sunan Ampel Al-Aly Uin Malang tahun angkatan 2012/2013 yang mengkonsumsi mie instan merek Indomie). Jurnal Administrasi Bisnis 2(1): 162-171.

Hsu C, Chen M. 2014. Explaining consumer attitudes and purchase intentions toward organic food: Contributions from regulatory fit and consumer characteristics. Food Quality and Preference 35: 6-13. https://doi.org/10.1016/j. foodqual.2014.01.005.

Hsu S, Chang C, Lin T. 2016. An analysis of purchase intentions toward organic food on health consciousness and food safety with/ under structural equation modeling. British Food Journal 118(1): 200- 216. https://doi. org/10.1108/BFJ-11-2014-0376.

Olsen S, Honkanen P, Verplanken B. 2006. Ethical values and motives driving organic food choice. Journal of Consumer Behaviour 5(5): 420-430. https://doi.org/10.1002/cb.190.

Kotler P, Keller K. 2013. Manajemen Pemasaran. Jakarta: Erlangga.

Kusumawardhani A. 2018. Pengaruh ekuitas merek terhadap minat beli dan keputusan pembelian sepatu bata berdasarkan sikap konsumen. [thesis]. Bogor: Institut Pertanian Bogor.

Liang R, Da. 2015. Predicting intentions to purchase organic food: the moderating effects of organic food prices. British Food Journal 1(118): 183199. https://doi.org/10.1108/BFJ-06-2015-0215.

Lindeman M, Vaananen M. 2000. Measurement of ethical food choice motives. Appetite (34): 5559. https://doi.org/10.1006/appe.1999.0293.

Marian L, Thøgersen J. 2013. Direct and mediated impacts of product and process characteristics on consumers' choice of organic vs conventional chicken. Food Quality and Preference 29(2): 106-112. https://doi.org/10.1016/j. foodqual.2013.03.001.

Marimaa K. 2011. The many face of fanaticism. ENDC Proceedings 14(2011): 29-55.

Norfarah N, Koo P, Nabiha A. 2018. Private label brand purchase intention: a malaysian study. Global Business and Management Research: An International Journal 10(1): 197-215.

Nugroho T, Sumarwan U, Kibrandoko. 2015. Factors influencing the purchase decision of organic tofu. Indonesian Journal of Business and Entrepreneurship 1(3):115-126. https://doi. org/10.17358/IJBE.1.3.115.

Pride WM, Ferrel OC. 2014. Marketing Seventeenth Edition. Mason: Southwestern.

Putra EW, Srikandi K, Edi Y. 2016. Pengaruh diskon terhadap minat beli serta dampaknya pada purchase decision. Jurnal Administrasi Bisnis 38(2): 184-193.

Redden J, Steiner C. 2000. Fanatical consumers: towards a framework for research. The Journal of Consumer Marketing 17(4): 322-337. https:// doi.org/10.1108/07363760010335349.

Sahota A. 2007. Overview of the global market for organic food and drink. The World of Organic Agriculture - Statistics and Emerging Trends 2007, International Federation of Organic Agriculture Movements (IFOAM), Bonn/ Research Institute of Organic Agriculture (FIBL), Frick.

Schobesberger BR, etal. 2007. Consumer perceptions of organic foods in Bangkok, Thailand. Food Policy 33(2008): 112-121. https://doi.org/10.1016/j. foodpol.2007.09.004.

Septifani, Fuad, Imam. 2014. Pengaruh green marketing, pengetahuan, dan minat beli terhadap purchase decision. JMT 13(2): 201-218. https:// doi.org/10.12695/jmt.2014.13.2.6. 
Siregar Ibrahim C, Najib M, Suparno O. 2019. Strategi pengembangan usaha tani tomat dalam upaya menembus singapura (studi kasus mitra tani parahyangan). Jurnal Aplikasi Manajemen dan Bisnis 5(1): 24-33.

Sivathanu B. 2015. Factors affecting consumer preference towards the organic food purchases. Indian Journal of Science and Technology 8(33): 1-6. https://doi.org/10.17485/ijst/2015/ v8i33/78261.

Steptoe A, Pollard T, Wardle J. 1995. Development of a measure of the motives underlying the selection of food: the food choice questionnaire. Appetite 25(3): 267-284.https://doi.org/10.1006/ appe.1995.0061.

Thorne S, Bruner G. 2006. An exploratory investigation of the characteristics of consumer fanaticism. Journal of Qualitative Market Research: An International Journal 9(1): 51-72. https://doi. org/10.1108/13522750610640558.

Tunc T, Karakas F, Cankaya S, Tasmektepligil M. 2016. Attitudes of the police candidates according to football supporter fanaticism scale. Journal of Sports and Exercise 18(2): 123-127. https://doi. org/10.15314/tjse.20544.

Willer H, Kilcher L. 2009. The World of Organic Agriculture. Statistics and Emerging Trends 2009, IFOAM, Bonn, and FiBL, Frick.

Wu PCS, Yeh GYY, Hsiao CR. 2011. The effect of store image and service quality on brand image and purchase intention for private label brands. Australasian Marketing Journal 19(1): 30-39. https://doi.org/10.1016/j.ausmj.2010.11.001.

ZeithamlV.1988. Consumerperceptions of price, quality and value: a means-end model and synthesis of evidence. Journal of Marketing 52(3): 2-22. https://doi.org/10.1177/002224298805200302. 